\title{
Empirical Analysis on the Sustainable Development of China's Outward Foreign Direct Investment from the Perspective of Economic Institution
}

\author{
Chang Wang, Juan Hong* \\ School of Economics and Management, Beijing University of Technology, Beijing 100124, China
}

Corresponding Author Email: hongjuan@ @jut.edu.cn

https://doi.org/10.18280/ijsdp.150314

Received: 10 October 2019

Accepted: 17 January 2020

\section{Keywords:}

outward foreign direct investment (OFDI), economic institutional distance, Belt and Road $(B \& R)$ strategy, institutional preference, sustainable development

\begin{abstract}
The countries along the Belt and Road (B\&R) are important destinations of China's outward foreign direct investment (OFDI). Based on the panel data (2003-2017) on China's OFDI in $65 \mathrm{~B} \& \mathrm{R}$ countries, this paper sets up a Heckman two-stage model, and then empirically analyzes how China's OFDI is affected by the difference between China and the host country in economic institution. In addition, the authors explored whether China has institutional preference in the OFDI with different investment motives. The empirical test shows that: investment selection and investment scale of China's OFDI are promoted to different degrees by the economic institution of the host country, and the absolute distance between China and the host country in economic institution; China has different institutional preferences in market-seeking OFDI between the selection stage and the investment stage; In terms of technology-seeking OFDI, host countries with short economic institutional distance are preferred in the selection stage, and host countries with good economic institution and long economic institutional distance are preferred in the investment stage. The research results provide empirical evidence for China to continuously implement OFDI in B\&R countries and create a green investment environment.
\end{abstract}

\section{INTRODUCTION}

As China further opens up to the world, the outward foreign direct investment (OFDI) from China is gaining momentum. Many multinational companies, in pursuit of green development, throng to invest and build factories in the countries along the Belt and Road (hereinafter referred to as the B\&R countries), a national strategy calling for the joint construction of the Green Silk Road. Their behaviors simulated the demand for green investment and financing, enhancing the growth potential of China's OFDI.

As shown in Figure 1, China's OFDI in the B\&R countries has trended up in recent years, reaching USD 15.64 billion, a year-on-year increase of $8.9 \%$. The steady and healthy growth of China's OFDI in these countries provides domestic companies with high development dividends, arousing the interest from the academia.

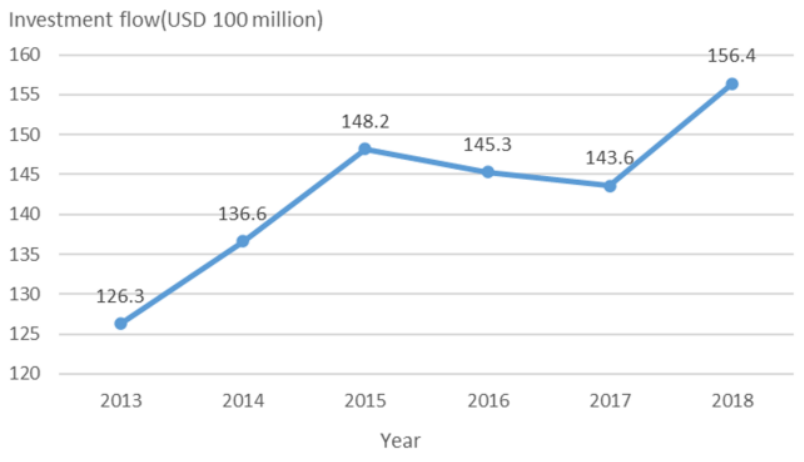

Figure 1. China's OFDI in the B\&R countries
The B\&R involves lots of countries that differ in economic level, economic institution and resource endowment. These differences, coupled with their limits in production capacity and market, pose a huge challenge to China's OFDI in these countries. To further improve its OFDI, China, as a government-led developing country, should develop and optimize its economic institution, creating a favorable business environment for the construction of the Green Silk Road.

Against this backdrop, this paper aims to investigate China's OFDI in the B\&R countries from the angle of economic institution, offer new empirical evidence about how to create a green investment environment, and provide institutional theories conducive to China's OFDI and the sustainable development of the B\&R countries.

\section{LITERATURE REVIEW}

\subsection{Institutional difference and China's OFDI}

Facing intensified international competition, many emerging economies weigh in on institutional system before making the OFDI [1-4]. Some studies on China's OFDI have started to consider the importance of economic institution [5]. Dunning [6] pointed out that the intuitional system provides a complete perspective to analyze and explain China's OFDI.

In fact, multinational companies have shifted their focus to the policy mechanism and incentive framework under the intuitional system of the host country, while making decisions about the OFDI [7]. China boasts special institutional 
advantages for the OFDI, which can be leveraged by multinational companies to implement their global strategies. The institutional advantages of the host country make up for the disadvantage of multinational companies in competitive resources, enabling them to achieve the goals of going global [8]. Kang and Jiang [9] suggested that China tends to seek strategic assets through the OFDI in countries with a very different institutional system, especially those with a much worse institutional system. Hayakawa and Matsuura [10] argued that a poor institutional system promotes the foreign direct investment (FDI) in the host country, making production more efficient.

In terms of political institution, policy support brings a key institutional advantage for multinational companies to conduct the OFDI, and thus an effective promoter of the OFDI [11]. In terms of economic institution, the OFDI in developing countries is greatly boosted by their economic institutions [1214]. Focusing on the economic institution of the host country, Witt and Lewin [15] noticed that China's OFDI is affected by multiple institutions of the host country, and described the effects as institutional incentives and institutional escape. In terms of cultural institution, China's OFDI is severely obstructed by the difference in cultural institution between China and the host country [16].

The existing studies have shown that the institutional gap between the home country and the host country has a certain impact on the OFDI by multinationals. Through empirical analysis, some scholars discovered that the institutional distancing effect of the said gap [17]. Other scholars proved that bilateral investment agreements influence the OFDI by the home country to varied degrees [18-20]. Aisbett et al. [21] found that bilateral investment agreements facilitate the OFDI by China and other developing countries, and help to reduce investment risks.

\subsection{Investment motives and China's OFDI}

The institutional preference of the OFDI varies with investment motives. Exploring the OFDI in different countries, scholars have proved the profound impacts of investment motives on corporate OFDI [22-24]. From the perspective of investment motives, Ramasamy et al. [25] probed deep into the location selection of China's OFDI, revealing that many state-owned enterprises tend to conduct the OFDI in countries with abundant natural resources, poor political environment, and high political risks. Considering the evolution of the spatiotemporal distribution, Li and Fabuš [26] empirically analyzed China's OFDI in the European Union (EU), and concluded that China's OFDI, seeking for both market and technology, is greatly affected by the investment freedom of the host country. Based on resource-seeking motives, Kolstad and Wiig [27] held that, through the OFDI, the home country aims to seek the resources that are rare or too costly to develop in the country, while countries rich in natural resources are often very corrupted.

\subsection{Thesis statements}

According to above analysis, many scholars have explored the impacts of institutional difference and investment motives on the OFDI, yielding fruitful results. China's OFDI has been examined from the perspective of institutional system. However, there is little report on China's OFDI in B\&R countries solely from the angle of economic institution, not to mention whether there exists institutional preference in the OFDI in B\&R countries under different investment motives.

Being a developing country, China now attaches greater importance to how institutional factors affect economic decisions. Meanwhile, most of B\&R countries are developing countries. In the context of the B\&R strategy, the economic institutions of China and the host country both have farreaching influence on China's OFDI.

This paper sets up a Heckman two-stage model based on the panel data (2003-2017) of 65 B\&R countries, and relies on the model to analyze how the investment selection and investment scale of China's OFDI are influenced by the economic institution of the host country and the absolute institutional distance between the host country and China. Special attention was paid to verify the existence of institutional preference in the OFDI with different investment motives.

The remainder of this paper is organized as follows: Section 3 sets up the Heckman two-stage model; Section 4 selects the variables and explains the data sources; Section 5 analyzes the empirical results; Section 6 puts forward the conclusions.

\section{MODEL CONSTRUCTION}

\subsection{Heckman model}

The research data are about China's OFDI in B\&R countries between 2013 and 2017. The original data are not continuous. Some data about a few countries in several years went missing, and some OFDI data were negative. These abnormal data demonstrate the selection bias of samples. The removal of such data will have a great impact on regression results. The model proposed by Heckman [28] provides a desirable tool to solve the selection bias.

Therefore, this paper employs the Heckman two-stage model for empirical test, and divides China's OFDI in B\&R countries into two stages: whether China invests in B\&R countries (selection stage); how much China invests in B\&R countries (investment stage). Based on the model of investment attraction [29], the selection and investment stages were respectively modelled as follows:

$$
\begin{gathered}
P_{r}\left(o f d i_{i t}\right)=\Phi\left(\alpha_{0}+\beta Y_{i j t}+\sum_{k} \theta Z_{i j t}+\mu_{i}+\mu_{j}\right. \\
\left.+\varepsilon_{i j t}\right) \\
o f d i_{i t}=\alpha_{0}+\beta Y_{i j t}+\sum_{k} \theta Z_{i j t}+\delta \gamma_{i j t}+\mu_{i}+\mu_{j} \\
+\varepsilon_{i j t}
\end{gathered}
$$

where, ofdi $i_{i t}$ (explained variable) is the OFDI flow from China to host country $\mathrm{i}$ along the B\&R at year $t$ (if ofdit $\mathrm{i}_{\mathrm{it}}>0$, then ofdi $\mathrm{i}_{\mathrm{it}}=1$; otherwise; ofdi $\mathrm{i}_{\mathrm{i}}=0$ ); $Y_{i j t}$ is the control variable; $Z_{i j t}$ is the core explanatory variables; $\alpha_{0}$ is the constant term; $\mu_{i}$ is the fixed-effect of country; $\mu_{j}$ is the fixed-effect of time; $\varepsilon_{i j t}$ is a random perturbation term; $\gamma_{i j t}$ is the inverse Mills ratio:

$$
\gamma_{i j t}=\frac{\phi\left[\alpha_{0}+\beta Y_{i j t}+\sum_{k} \theta Z_{i j t}+\mu_{i}+\mu_{j}+\varepsilon_{i j t}\right]}{\Phi\left[\alpha_{0}+\beta Y_{i j t}+\sum_{k} \theta Z_{i j t}+\mu_{i}+\mu_{j}+\varepsilon_{i j t}\right]}
$$

where, $\Phi[\bullet]$ is the probability distribution function of the standard normal distribution; $\phi[\bullet]$ is the probability density function. If $\gamma_{i j t} \neq 0$, then $\gamma_{i j t}$ is significant, which signifies sample 
self-selection. In this case, $\gamma_{i j t}$ effectively overcomes the selection bias, making it suitable to use the Heckman model.

\subsection{Benchmark model}

According to Heckman's two-stage model, the absolute distance between China and the host country in economic institution was taken as the core explanatory variable to explore the influence mechanism of economic institution on China's OFDI. The benchmark model was established as follows:

$$
\begin{aligned}
\operatorname{Pr}\left(o f d i_{i t}\right)=\Phi[ & \alpha_{0}+\beta_{1} \ln \left(R_{i(t-1)}\right) \\
& +\beta_{2} \ln \left(H P G D P_{i(t-1)}\right) \\
& +\beta_{3} \ln \left(H G D P_{i(t-1)}\right) \\
& +\beta_{4} \ln \left(H T_{i(t-1)}\right) \\
+\beta_{5}\left(F D I I_{i(t-1)}\right)+ & \beta_{6} \ln \left(B E R_{i(t-1)}\right)+\sum_{k} \theta_{k} Z_{i j t}^{k} \\
& +\lambda B T R_{i j t}+\delta \gamma_{i j t}+\mu_{i}+\mu_{j} \\
& \left.+\varepsilon_{i j t}\right] \\
\ln \left(o f d i_{i t}\right)=\alpha_{0}+ & \beta_{1} \ln \left(R_{i(t-1)}\right) \\
+ & \beta_{2} \ln \left(H P G D P_{i(t-1)}\right) \\
+ & \beta_{3}\left(H G D P_{i(t-1)}\right) \\
+ & \beta_{4} \ln \left(H T_{i(t-1)}\right) \\
+\beta_{5} \ln \left(F D I I_{i(t-1)}\right) & +\beta_{6}\left(B E R_{i(t-1)}\right)++\sum_{k} \theta_{k} Z_{i j t}^{k} \\
+ & \delta \gamma_{i j t}+\mu_{i}+\mu_{j}+\varepsilon_{i j t}
\end{aligned}
$$

where, ofdi $i_{i t}$ is China's OFDI in the host country (if ofd $\mathrm{i}_{\mathrm{it}}>0$, then ofdi $\mathrm{it}_{\mathrm{it}}=1$; otherwise; ofdi $\left._{\mathrm{it}}=0\right)$; $R, H P G D P, H G D P, H T$ and FDII (control variables) are resource endowment, market opportunities, market size, technical level and FDI inward of the host country, respectively; BER (control variable) is the bilateral exchange rate between China and the host country; $Z_{i j t}$ is the core explanatory variables, including the economic institution of the host country (HEI) and the absolute distance between China and the host country in economic institution $(E I D) ; B T R$ is the bilateral trade relation between China and the host country; $t$ is the time factor lagged by one period to prevent endogenous problems; $\gamma_{i j t}$ is the inverse Mills ratio (If $\gamma_{i j t} \neq 0$, then $\gamma_{i j t}$ effectively overcomes the selection bias, making it suitable to use the Heckman model).

According to the principle of Heckman's two-stage empirical test, the select function must contain at least one exclusive explanatory variable, such that the regression coefficients are legible. The BTR determines whether China will make the OFDI in the host country, without affecting the investment scale. The bilateral trade relation directly bears on the smoothness of China's OFDI in the host country. Therefore, the BTR was selected as an exclusive explanatory variable of the selection function.

\section{VARIABLE SELECTION AND DATA SOURCES}

Based on the panel data (2003-2017) of 65 B\&R countries, our research involves the following variables:

\subsection{Explained variable}

The OFDI flow, denoted as $O F D I$, was taken as the explained variable: the flow of China's OFDI in the 65 host countries along the B\&R.

\subsection{Explanatory variables}

(1) The economic institution of each host country was measured by the ECONIST index (HEI).

(2) The absolute distance between China and the host country was measured by economic institutional distance (EID).

(3) The quality of the economic institution of a county was measured by the Index of Economic Freedom (EFI) released by The Heritage Foundation. The EFI value is the average of

\begin{tabular}{|c|c|c|}
\hline $\begin{array}{l}\text { Variable } \\
\text { name }\end{array}$ & $\begin{array}{c}\text { Variable } \\
\text { description }\end{array}$ & $\begin{array}{c}\text { Data } \\
\text { sources }\end{array}$ \\
\hline OFDI & $\begin{array}{l}\text { China's foreign } \\
\quad \text { direct } \\
\text { investment flows }\end{array}$ & $\begin{array}{l}\text { Chinese Ministry of } \\
\text { Commerce } \\
\text { China's Foreign Direct } \\
\text { Investment Statistics } \\
\text { Bulletin }\end{array}$ \\
\hline HEI & $\begin{array}{l}\text { The economic } \\
\text { institution of each host } \\
\text { country }\end{array}$ & $\begin{array}{l}\text { American Heritage } \\
\text { Foundation }\end{array}$ \\
\hline EID & $\begin{array}{l}\text { Absolute distance } \\
\text { between host country } \\
\text { and China's economic } \\
\text { system }\end{array}$ & $\begin{array}{l}\text { American Heritage } \\
\text { Foundation }\end{array}$ \\
\hline BTR & $\begin{array}{l}\text { Bilateral trade } \\
\text { relations }\end{array}$ & $\begin{array}{l}\text { Statistical yearbook of } \\
\text { China }\end{array}$ \\
\hline $\mathrm{R}$ & $\begin{array}{l}\text { The resource } \\
\text { endowment of the host } \\
\text { country }\end{array}$ & World Bank database \\
\hline HPGDP & $\begin{array}{l}\text { The market } \\
\text { opportunities of the } \\
\text { host country }\end{array}$ & $\begin{array}{c}\text { World Bank World } \\
\text { Development Indicators } \\
\text { (WDI) }\end{array}$ \\
\hline HGDP & $\begin{array}{l}\text { The market size of } \\
\text { the host country }\end{array}$ & $\begin{array}{c}\text { World Bank World } \\
\text { Development Indicators } \\
\text { (WDI) }\end{array}$ \\
\hline HT & $\begin{array}{l}\text { The technical level } \\
\text { of the host country }\end{array}$ & $\begin{array}{c}\text { World Bank World } \\
\text { Development Indicators } \\
\text { (WDI) }\end{array}$ \\
\hline FDII & $\begin{array}{l}\text { The FDI inward of } \\
\text { the host country }\end{array}$ & $\begin{array}{l}\text { UNCTAD's FDI } \\
\text { database }\end{array}$ \\
\hline BER & $\begin{array}{l}\text { The bilateral } \\
\text { exchange rate }\end{array}$ & $\begin{array}{l}\text { UNCTAD's FDI } \\
\text { database }\end{array}$ \\
\hline
\end{tabular}
12 relevant secondary indices, namely, property rights, judicial effectiveness, government integrity, tax burden, government spending, fiscal health, business freedom, labor freedom, monetary freedom, trade freedom, investment freedom, and financial freedom. The EFI is an accurate yardstick of economic freedom of a country.

(4) The bilateral trade relation (BTR), the exclusive explanatory variable, was measured by the total trade between China and the B\&R countries. The data were extracted from China Statistical Yearbooks.

\subsection{Control variables}

Table 1. List of variables and data sources

(1) The resource endowment $(R)$ of the host country was measured by the sum of the country's exports of metal, fuel and ore.

(2) The market opportunities (HPGDP) of the host country were measured by the per-capita GDP [30, 31].

(3) The market size $(H G D P)$ of the host country was 
explanatory variables, the economic institution of the host country and the economic institutional distance between China and the host country have profound impacts on whether and how much China invests in B\&R countries. This means economic institution is the key consideration of China in its implementation of the OFDI.

On the test results of control variables, $\mathrm{R}$ was insignificant in the first stage and significantly negative in the second stage: the resource endowment of the host country does not greatly affect whether China invests in that country, but significantly suppresses the investment scale. HPGDP was significantly negative in the first stage and significantly positive in the second stage: the fewer the market opportunities in the host country, the more likely for China to invest in that country, but the smaller the scale of China's OFDI. HGDP and HT were insignificant in the first and second stages: China's OFDI has little to do with the market size and technical level of the host country. China does not pursue a large market or advanced techniques through the OFDI in B\&R countries, because these countries are mostly developing countries with relatively backward economy. FDII was insignificant in the first stage and significantly negative in the second stage: the FDI inward of the host country does not greatly affect whether China invests in that country, but significantly boosts the investment scale. The significance of BER was not stable: China's OFDI was not greatly influenced by bilateral exchange rate.

\subsection{Institution and investment motives}

Investment motive is a critical factor in corporate OFDI. With the change of investment motive, China might choose to conduct OFDI in another country, or invest on a different scale. The preliminary results show that HPGDP and R of the host country affect China's OFDI to varied degrees, while HT of the host country does not exert any significant impact on China's OFDI. However, two questions remain to be answered: How does the difference between the host country and China in economic institution affects China's OFDI motive? Whether there exists institutional preference in China's OFDI with different motives. To answer these questions, this paper carries out an orthogonal test between three OFDI motives (i.e. HPGDP, R and HT) and two core explanatory variables (i.e. HEI and EID). The test results are recorded in Table 5.

Table 5. Regression results of the relationship between economic institution and each OFDI motive

\begin{tabular}{|c|c|c|c|c|c|c|c|c|c|c|c|c|}
\hline \multirow[b]{2}{*}{ Variable } & \multicolumn{2}{|c|}{$(1)$} & \multicolumn{2}{|c|}{$(2)$} & \multicolumn{2}{|c|}{ (3) } & \multicolumn{2}{|c|}{ (4) } & \multicolumn{2}{|c|}{$(5)$} & \multicolumn{2}{|c|}{ (6) } \\
\hline & $\begin{array}{l}\text { Selection } \\
\text { function }\end{array}$ & $\begin{array}{l}\text { Investment } \\
\text { function }\end{array}$ & $\begin{array}{l}\text { Selection } \\
\text { function }\end{array}$ & $\begin{array}{l}\text { Investment } \\
\text { function }\end{array}$ & $\begin{array}{l}\text { Selection } \\
\text { function }\end{array}$ & $\begin{array}{l}\text { Investment } \\
\text { function }\end{array}$ & $\begin{array}{l}\text { Selection } \\
\text { function }\end{array}$ & $\begin{array}{l}\text { Investment } \\
\text { function }\end{array}$ & $\begin{array}{l}\text { Selection } \\
\text { function }\end{array}$ & $\begin{array}{l}\text { Investment } \\
\text { function }\end{array}$ & $\begin{array}{l}\text { Selection } \\
\text { function }\end{array}$ & $\begin{array}{l}\text { Investment } \\
\text { function }\end{array}$ \\
\hline $\begin{array}{c}\text { HPGDP } \\
\times \text { HEI }\end{array}$ & $\begin{array}{c}-7.770 * * \\
(-2.49)\end{array}$ & $\begin{array}{c}5.613 * * * \\
(5.98)\end{array}$ & & & & & & & & & & \\
\hline $\begin{array}{l}\text { HPGDP } \\
\times \text { EID }\end{array}$ & & & $\begin{array}{c}-3.540 * * * \\
(-3.16)\end{array}$ & $\begin{array}{c}2.431 * * * \\
(8.88)\end{array}$ & & & & & & & & \\
\hline $\mathrm{R} \times \mathrm{HEI}$ & & & & & $\begin{array}{l}6.050 \\
(1.32)\end{array}$ & $\begin{array}{l}-1.939 \\
(-1.26)\end{array}$ & & & & & & \\
\hline $\mathrm{R} \times \mathrm{EID}$ & & & & & & & $\begin{array}{l}-1.370 \\
(-0.18)\end{array}$ & $\begin{array}{l}-2.485 \\
(-0.98)\end{array}$ & & & & \\
\hline $\mathrm{HT} \times \mathrm{HEI}$ & & & & & & & & & $\begin{array}{l}-0.000 \\
(-0.50)\end{array}$ & $\begin{array}{c}9.103 * * * \\
(2.96)\end{array}$ & & \\
\hline HT $\times$ EID & & & & & & & & & & & $\begin{array}{c}-0.029 * \\
(-1.86)\end{array}$ & $\begin{array}{c}1.153^{* *} \\
(3.62)\end{array}$ \\
\hline BTR & $\begin{array}{c}0.000 * * * \\
(4.95)\end{array}$ & & $\begin{array}{c}0.000 * * * \\
(4.88)\end{array}$ & & $\begin{array}{c}0.000 * * * \\
(5.12)\end{array}$ & & $\begin{array}{c}0.000 * * * \\
(5.13)\end{array}$ & & $\begin{array}{c}0.000 * * * \\
(5.09)\end{array}$ & & $\begin{array}{c}0.000 * * * \\
(5.17)\end{array}$ & \\
\hline $\mathrm{R}$ & $\begin{array}{l}0.002 \\
(0.72)\end{array}$ & $\begin{array}{l}-1.270 \\
(-1.62)\end{array}$ & $\begin{array}{l}0.005 \\
(1.64)\end{array}$ & $\begin{array}{c}-2.352 * * * \\
(-3.01)\end{array}$ & $\begin{array}{c}-7.390 * * * \\
(-3.34)\end{array}$ & $\begin{array}{c}2.981 * * * \\
(3.95)\end{array}$ & $\begin{array}{c}-5.900 * * * \\
(-2.91)\end{array}$ & $\begin{array}{c}2.710 * * * \\
(3.98)\end{array}$ & $\begin{array}{l}0.004 \\
(1.39)\end{array}$ & $\begin{array}{l}-1.056 \\
(-1.25)\end{array}$ & $\begin{array}{l}0.004 \\
(1.34)\end{array}$ & $\begin{array}{l}-1.062 \\
(-1.29)\end{array}$ \\
\hline HGDP & $\begin{array}{l}-0.031 \\
(-0.59)\end{array}$ & $\begin{array}{l}1.084 \\
(0.87)\end{array}$ & $\begin{array}{l}-0.063 \\
(-1.10)\end{array}$ & $\begin{array}{c}2.159 * \\
(1.84)\end{array}$ & $\begin{array}{l}-0.021 \\
(-0.43)\end{array}$ & $\begin{array}{c}1.316 \\
(1.03)\end{array}$ & $\begin{array}{l}-0.018 \\
(-0.38)\end{array}$ & $\begin{array}{l}1.301 \\
(1.02)\end{array}$ & $\begin{array}{c}-7.320 * * * \\
(-3.37)\end{array}$ & $\begin{array}{c}2.849 * * * \\
(3.99)\end{array}$ & $\begin{array}{c}-7.140 * * * \\
(-3.29)\end{array}$ & $\begin{array}{c}2.404 * * * \\
(3.27)\end{array}$ \\
\hline HT & $\begin{array}{l}-0.006 \\
(-0.06)\end{array}$ & $\begin{array}{l}-3.860 \\
(-1.12)\end{array}$ & $\begin{array}{l}0.010 \\
(0.09)\end{array}$ & $\begin{array}{c}-6.490^{*} \\
(-1.94)\end{array}$ & $\begin{array}{l}0.004 \\
(0.03)\end{array}$ & $\begin{array}{l}-1.325 \\
(-0.38)\end{array}$ & $\begin{array}{l}-0.045 \\
(-0.41)\end{array}$ & $\begin{array}{l}-7.164 \\
(-0.21)\end{array}$ & & $\begin{array}{l}2.116 \\
(1.64)\end{array}$ & $\begin{array}{l}-0.039 \\
(-0.70)\end{array}$ & $\begin{array}{c}2.101^{*} \\
(1.68)\end{array}$ \\
\hline FDII & $\begin{array}{l}-0.672 \\
(-1.30)\end{array}$ & $\begin{array}{c}1.061 * * * \\
(4.41)\end{array}$ & $\begin{array}{l}-0.548 \\
(-1.03)\end{array}$ & $\begin{array}{c}9.014 * * * \\
(3.84)\end{array}$ & $\begin{array}{l}-0.613 \\
(-1.17)\end{array}$ & $\begin{array}{c}1.169 * * * \\
(4.79)\end{array}$ & $\begin{array}{l}-0.632 \\
(-1.21)\end{array}$ & $\begin{array}{c}1.150 * * * \\
(4.74)\end{array}$ & $\begin{array}{l}-0.594 \\
(-1.13)\end{array}$ & $\begin{array}{c}1.031 * * * \\
(4.22)\end{array}$ & $\begin{array}{l}-0.546 \\
(-1.03)\end{array}$ & $\begin{array}{c}1.016^{* * * *} \\
(4.18)\end{array}$ \\
\hline BER & $\begin{array}{l}-0.015 \\
(-1.45)\end{array}$ & $\begin{array}{c}-9.256^{* *} \\
(-2.02)\end{array}$ & $\begin{array}{c}-0.019 * \\
(-1.90)\end{array}$ & $\begin{array}{l}-5.875 \\
(-1.38)\end{array}$ & $\begin{array}{l}-0.016 \\
(-1.58)\end{array}$ & $\begin{array}{l}-5.359 \\
(-1.15)\end{array}$ & $\begin{array}{l}-0.012 \\
(-1.24)\end{array}$ & $\begin{array}{l}-7.098 \\
(-1.59)\end{array}$ & $\begin{array}{l}-0.014 \\
(-1.35)\end{array}$ & $\begin{array}{l}-7.118 \\
(-1.58)\end{array}$ & $\begin{array}{l}-0.012 \\
(-1.19)\end{array}$ & $\begin{array}{l}-6.973 \\
(-1.58)\end{array}$ \\
\hline Mills & $\begin{array}{c}-5.317 * * * \\
(-3.37)\end{array}$ & $\begin{array}{c}-5.317 * * * \\
(-3.37)\end{array}$ & $\begin{array}{c}-5.340 * * * \\
(-3.50)\end{array}$ & $\begin{array}{c}-5.340 * * * \\
(-3.50)\end{array}$ & $\begin{array}{c}-5.594 * * * \\
(-3.58)\end{array}$ & $\begin{array}{c}-5.594 * * * * \\
(-3.58)\end{array}$ & $\begin{array}{c}-5.262 * * * \\
(-3.42)\end{array}$ & $\begin{array}{c}-5.262 * * * \\
(-3.42)\end{array}$ & $\begin{array}{c}-4.910 * * * \\
(-3.50)\end{array}$ & $\begin{array}{c}-4.910 * * * \\
(-3.50)\end{array}$ & $\begin{array}{c}-3.972 * * * \\
(-2.71)\end{array}$ & $\begin{array}{c}-3.972 * * * \\
(-2.71)\end{array}$ \\
\hline Constant & $\begin{array}{l}-4.618 \\
(-1.54)\end{array}$ & $\begin{array}{c}-2.264^{*} \\
(-1.91)\end{array}$ & $\begin{array}{l}-3.325 \\
(-1.09)\end{array}$ & $\begin{array}{c}-2.262 * * \\
(-2.00)\end{array}$ & $\begin{array}{l}-3.666 \\
(-1.22)\end{array}$ & $\begin{array}{c}-2.612 * * \\
(-2.20)\end{array}$ & $\begin{array}{l}-3.947 \\
(-1.32)\end{array}$ & $\begin{array}{c}-2.689 * * \\
(-2.28)\end{array}$ & $\begin{array}{l}-4.155 \\
(-1.38)\end{array}$ & $\begin{array}{c}-2.114^{*} \\
(-1.89)\end{array}$ & $\begin{array}{l}-4.500 \\
(-1.49)\end{array}$ & $\begin{array}{c}-2.680 * * \\
(-2.34)\end{array}$ \\
\hline LR & $\begin{array}{c}1.69 \\
(0.000) \\
\end{array}$ & $\begin{array}{c}1.69 \\
(0.000) \\
\end{array}$ & $\begin{array}{c}1.93 \\
(0.000)\end{array}$ & $\begin{array}{c}1.93 \\
(0.000) \\
\end{array}$ & $\begin{array}{c}2.09 \\
(0.000) \\
\end{array}$ & $\begin{array}{c}2.09 \\
(0.000) \\
\end{array}$ & $\begin{array}{c}2.09 \\
(0.000) \\
\end{array}$ & $\begin{array}{c}2.09 \\
(0.000) \\
\end{array}$ & $\begin{array}{c}2.00 \\
(0.000) \\
\end{array}$ & $\begin{array}{c}2.00 \\
(0.000) \\
\end{array}$ & $\begin{array}{c}1.97 \\
(0.000)\end{array}$ & $\begin{array}{c}1.97 \\
(0.000) \\
\end{array}$ \\
\hline
\end{tabular}

Note: Selection function and investment function are the results of the first and second stages, respectively; ${ }^{* *}$ and $* * *$ are the significance levels of $10 \%, 5 \%$ and $1 \%$, respectively; LR is the likelihood ratio that reflects the significance of the inverse Mills ratio, i.e. the presence of sample self-selection.

(1) The regression results on the interaction terms between HPGDP and the two institutional variables

The coefficients of HPGDP $\times$ HEI and HPGDP $\times$ EID were both significantly negative in the first stage, and significantly positive in the second stage: the better the economic institution of the host country, China is less likely to conduct market- seeking OFDI in that country; if China decides to make OFDI in that country, the investment scale increases with the quality of economic institution. The inverse is also true. The main reason is that a host country with a high-quality economic institution, i.e. a good investment environment, easily attracts lots of multinational companies; any attempt of the OFDI will 
face excessive competitions. If the host country has a poor economic institution, i.e. a bad investment environment, the OFDI in that country will face little competition and enjoy a huge potential of growth, despite some inevitable obstacles. The above results fully demonstrate the institutional preferences of China's market-seeking OFDI: host countries with poor economic institution and a long economic institutional distance are preferred in the selection stage, and host countries with good economic institution and a short economic institutional distance are preferred in the investment stage.

(2) The regression results on the interaction terms between $\mathrm{R}$ and the two institutional variables

The coefficients of $\mathrm{R} \times \mathrm{HEI}$ and $\mathrm{R} \times \mathrm{EID}$ were insignificant in the first and second stages. There are three possible causes: Firstly, China's OFDI is not affected by the resource endowment of the host country (see previous regression results), i.e. China does not regard the quality of economic institution as the primary requirement, when it selects the host country of its OFDI. Secondly, most of our samples are developing countries with a small economic aggregate. Except Russia and India, the other B\&R countries are small in size and scarce in resources. The few oil-rich countries (e.g. Iraq) cannot change the overall test results. Lastly but not the least, the recent boom in digital economy has given birth to a number of multinational enterprises engaging in big data, artificial intelligence and 5G. Due to the emergence and expansion of such enterprises, China's OFDI motives have gradually shifted from acquisition of market, resources and technology towards that of knowledge, finance and tax.

(3) The regression results on the interaction terms between HT and the two institutional variables

$\mathrm{HT} \times \mathrm{HEI}$ was insignificant in the first stage, and significantly positive in the second stage: the economic institution of the host country has not significant impact on whether China makes technology-seeking OFDI in that country; if China decides to make OFDI in that country, the investment scale increases with the quality of economic institution. HT $\times$ EID was significantly negative in the first stage and significantly positive in the second stage: the greater the host country differs with China in economic institution, the less likely for China to make technology-seeking OFDI in that country; if China decides to make OFDI in that country, the investment scale increases with the difference in economic institution. The above results manifest the institutional preferences of China's technology-seeking OFDI: host countries with short economic institutional distance are preferred in the selection stage, and host countries with good economic institution and long economic institutional distance are preferred in the investment stage.

\section{CONCLUSIONS}

Based on the panel data (2003-2017) on China's OFDI in 65 B\&R countries, this paper sets up a Heckman two-stage model, and relies on the model to analyze how the investment selection and investment scale of China's OFDI are influenced by the economic institution of the host country. The authors also tested the existence of institutional preference in the OFDI with different investment motives. The following results were drawn through empirical test:

(1) The economic institution of the host country and the absolute distance between China and the host country in economic institution have little impact on whether China implements the OFDI, but positively affect the OFDI scale.

(2) The market opportunities in the host country significantly suppress China's OFDI in that country, but greatly promote the investment scale, if China decides to invest in that country.

(3) China has different institutional preferences in marketseeking OFDI between the two stages: host countries with poor economic institution and a long economic institutional distance are preferred in the selection stage, and host countries with good economic institution and a short economic institutional distance are preferred in the investment stage.

(4) China does not have any institutional preference in resource-seeking OFDI.

(5) In terms of technology-seeking OFDI, host countries with short economic institutional distance are preferred in the selection stage, and host countries with good economic institution and long economic institutional distance are preferred in the investment stage.

In the context of reform and opening-up and the B\&R strategy, China should pay close attention to how the institutional quality changes in the host country before selecting the investment target and making investment decisions; the institutional risks should be fully analyzed in the light of investment motive. In this way, it is possible to make reasonable investment decisions in a world with diverse economic institutions and complex economic situation, thereby improving the health and sustainability of China's OFDI.

\section{REFERENCES}

[1] Morck, R., Yeung, B., Zhao, M. (2008). Perspectives on China's outward foreign direct investment. Journal of International Business Studies, 39(3): 337-350. https://doi.org/10.1057/palgrave.jibs.8400366

[2] Lewin, A.Y., Kim, J. (2004). The nation-state and culture as influences on organizational change and innovation. Handbook of Organizational Change and Innovation, 324-353.

[3] Redding, G. (2005). The thick description and comparison of societal systems of capitalism. Journal of International Business Studies, 36(2): 123-155. https://doi.org/10.1057/palgrave.jibs.8400129

[4] Ring, P.S., Bigley, G.A., D'Aunno, T., Khanna, T. (2005) Perspectives on how governments matter. Academy of Management Review, 30(2): 308-320.

[5] Luo, Y., Xue, Q., Han, B. (2010). How emerging market governments promote outward FDI: Experience from China. Journal of World Business, 45(1): 68-79. https://doi.org/10.1016/j.jwb.2009.04.003

[6] Dunning, J.H. (2006). Comment on dragon multinationals: New players in 21 st century globalization. Asia Pacific Journal of Management, 23(2): 139-141. https://doi.org/10.1007/s10490-006-7161-1

[7] Pereira de Carvalho, F., Goldstein, A. (2008). The making of national giants: Technology and governments shaping the international expansion of oil companies from Brazil and China (No. 021). United Nations University-Maastricht Economic and Social Research Institute on Innovation and Technology (MERIT).

[8] Wang, C., Hong, J., Kafouros, M., Wright, M. (2012). Exploring the role of government involvement in 
outward FDI from emerging economies. Journal of International Business Studies, 43(7): 655-676. https://doi.org/10.1057/jibs.2012.18

[9] Kang, Y., Jiang, F. (2012). FDI location choice of Chinese multinationals in East and Southeast Asia: Traditional economic factors and institutional perspective. Journal of World Business, 47(1): 45-53. https://doi.org/10.1016/j.jwb.2010.10.019

[10] Hayakawa, K., Matsuura, T. (2011). Complex vertical FDI and firm heterogeneity: Evidence from East Asia. Journal of the Japanese and International Economies, 25(3):

273-289. https://doi.org/10.1016/j.jjie.2011.06.004

[11] Hikino, T., Amsden, A.H. (1994). Staying behind, stumbling back, sneaking up, soaring ahead: late industrialization in historical perspective. Convergence of Productivity: Cross-National Studies and Historical Evidence, 285-315.

[12] Wang, C., Hong, J., Kafouros, M., Boateng, A. (2012). What drives outward FDI of Chinese firms? Testing the explanatory power of three theoretical frameworks. International Business Review, 21(3): 425-438. https://doi.org/10.1016/j.ibusrev.2011.05.004

[13] Blonigen, B.A. (2005). A review of the empirical literature on FDI determinants. Atlantic Economic Journal, 33(4): 383-403. https://doi.org/10.1007/s11293005-2868-9

[14] Yiu, D.W., Lau, C., Bruton, G.D. (2007). International venturing by emerging economy firms: The effects of firm capabilities, home country networks, and corporate entrepreneurship. Journal of International Business $\begin{array}{lll}\text { Studies, } & 38(4) \text { : } & \text { 519-540. }\end{array}$ https://doi.org/10.1057/palgrave.jibs.8400278

[15] Witt, M.A., Lewin, A.Y. (2007). Outward foreign direct investment as escape response to home country institutional constraints. Journal of International Business $\quad$ Studies, $38(4)$ : $579-594$. https://doi.org/10.1057/palgrave.jibs.8400285

[16] Yiu, D., Makino, S. (2002). The choice between joint venture and wholly owned subsidiary: An institutional perspective. Organization Science, 13(6): 667-683. https://doi.org/10.1287/orsc.13.6.667.494

[17] Godinez, J.R., Liu, L. (2015). Corruption distance and FDI flows into Latin America. International Business Review, 24(1): 33-42. https://doi.org/10.1016/j.ibusrev.2014.05.006

[18] Jacobs, M.N. (2017). Do bilateral investment treaties attract foreign direct investment to developing countries? A review of the empirical literature. International Relations, 5(10): 583-593.

[19] Colen, L., Persyn, D., Guariso, A. (2016). Bilateral investment treaties and FDI: Does the sector matter? World Development, 83: 193-206. https://doi.org/10.1016/j.worlddev.2016.01.020

[20] Frenkel, M., Walter, B. (2019). Do bilateral investment treaties attract foreign direct investment? The role of international dispute settlement provisions. The World Economy, 42(5): 1316-1342. https://doi.org/10.1111/twec.12743

[21] Aisbett, E., Busse, M., Nunnenkamp, P. (2018). Bilateral investment treaties as deterrents of host-country discretion: The impact of investor-state disputes on foreign direct investment in developing countries. Review of World Economics, 154(1): 119-155. https://doi.org/10.1007/s10290-017-0285-1

[22] Urzelai, B., Puig, F. (2019). The value of local externalities in country-of-origin clusters: Evidence from China. In the Changing Strategies of International Business, 117-133. https://doi.org/10.1007/978-3-03003931-8_6

[23] Liu, H.C.I., Uchida, Y., Norasakkunkit, V. (2019). Socio-economic marginalization and compliance motivation among students and freeters in Japan. Frontiers in Psychology, 10: 312. https://doi.org/10.3389/fpsyg.2019.00312

[24] Zhang, H. (2019). Institutional Distance, Investment motivation and OFDI location-taking the countries along the "Belt and Road" as an example. Open Journal of Social Sciences, 7(2): 118-131. https://doi.org/10.4236/jss.2019.72009

[25] Ramasamy, B., Yeung, M., Laforet, S. (2012). China's outward foreign direct investment: Location choice and firm ownership. Journal of World Business, 47(1): 17-25. https://doi.org/10.1016/j.jwb.2010.10.016

[26] Li, S., Fabuš, M. (2019). Study on the spatial distribution of China's Outward Foreign Direct Investment in EU and its influencing factors. Entrepreneurship and Sustainability Issues, 6(3): 1080-1096.

[27] Kolstad, I., Wiig, A. (2009). Is transparency the key to reducing corruption in resource-rich countries? World Development, 37(3): 521-532. https://doi.org/10.1016/j.worlddev.2008.07.002

[28] Heckman, J.J. (1979). Sample selection bias as a specification error. Econometrica, 47(1): 153-61.

[29] Anderson, J.E. (1979). A theoretical foundation for the gravity equation. The American Economic Review, 69(1): 106-116.

[30] Eaton, J., Tamura, A. (1995). Bilateralism and regionalism in Japanese and US trade and direct foreign investment patterns, w4758.

[31] Lane, P.R. (2000). International investment positions: a cross-sectional analysis. Journal of International Money and $\quad$ Finance, $19(4)$ : 513-534. https://doi.org/10.1016/S0261-5606(00)00019-X

[32] Wheeler, D., Mody, A. (1992). International investment location decisions: The case of US firms. Journal of International Economics, 33(1-2): 57-76. https://doi.org/10.1016/0022-1996(92)90050-T

[33] Frankel, J., Wei, S.J. (1997). ASEAN in a Regional Perspective. Macroeconomic Issues Facing ASEAN Countries. 